\title{
Hypercoagulability risk factors associated with venous thromboembolic events in patients with idiopathic membranous nephropathy and nephrotic syndrome: a prospective observational study
}

\author{
Factori de risc pentru hipercoagulabilitate asociați evenimentelor \\ tromboembolice la pacienții cu nefropatie membranoasă idiopatică şi \\ sindrom nefrotic: studiu observațional prospectiv
}

Gener Ismail $^{1 *}$, Mihai Harza ${ }^{1}$, Liliana Tuta ${ }^{2}$, Roxana Jurubita ${ }^{1}$, Otilia Motoi ${ }^{1}$, Alecse Valerian Ditoiu ${ }^{1}$

1. Department of Nephrology, Urology, Transplant Immunology, Dermatology and Allergology,

"Carol Davila" University of Medicine and Pharmacy, Bucharest, Romania

2. Department of Nephrology, "Ovidius" University of Medicine and Pharmacy, Constanta, Romania

\begin{abstract}
Background: The nephrotic syndrome (NS) is associated with an increased incidence of thromboembolic complications due to multiple abnormalities in haemostasis and the coagulation system occurring in these patients. We aimed to assess prospectively the risk of venous thromboembolic events (VTE) in a large cohort of NS patients and to identify predictive factors for VTE, especially haemostasis-related parameters. Methods: We performed a prospective observational study including consecutive adult patients with idiopathic membranous nephropathy and NS. The diagnosis of NS was confirmed by the presence of a daily protein excretion greater than $3.5 \mathrm{~g}$. Clinical and biological data, including coagulation and fibrinolytic system-related parameters, were obtained every 6 months during follow-up. Occurrence of VTE was the primary outcome of the study. Results: We enrolled 56 patients (52 \pm 11 years, 64\% men). Median follow-up time was 12 [IQR: 12, 33] months. During follow-up 11 VTE occurred, $91 \%$ of them in the first six months. Baseline proteinuria and serum albumin were associated with VTE ( $p<0.001)$. As for the haemostatic parameters, antithrombin III (ATIII) activity, protein C activity, plasminogen activator inhibitor-1 (PAI-1) and tisular plasminogen activator (tPA) levels were associated with an increased risk of VTE (all p<0.05), while protein $S$ activity and fibrinogen were not. At multivariable analysis only ATIII activity $(\operatorname{Exp}(B) 0.86,95 \%$ CI 0.75 to 0.98; $p=0.027)$ and serum albumin $(\operatorname{Exp}(B) 0.062,95 \%$ CI 0.01 to 0.37; $p=0.002)$ remained independently associated with VTE. Conclusion: In this prospective study the risk of VTE was higher in the first 6 months of follow-up. Among the haemostasis-related parameters, only ATIII deficiency emerged as VTE independent risk factor in adult patients with idiopathic membranous nephropathy and NS.
\end{abstract}

Keywords: Antithrombin III, D-dimers, membranous nephropathy, nephrotic syndrome, thrombosis.

*Corresponding author: Gener Ismail, "Carol Davila” University of Medicine and Pharmacy, Department of Nephrology, Urology, Transplant Immunology, Dermatology and Allergology, Str. Dionisie Lupu Nr. 37, Sector 1, 020021, Bucharest, Romania. Email: gener732000@yahoo.com, Tel: 0722792429 


\section{Rezumat}

Introducere: Sindromul nefrotic (SN) este asociat cu o incidență crescută a complicațiilor tromboembolice datorită multiplelor anomalii ale sistemul coagulării şi al hemostazei întâlnite la aceşti pacienți. Ne-am propus sa evaluăm prospectiv riscul evenimentelor venoase tromboembolice (ETV) intr-o cohorta mare de pacienți cu sindrom nefrotic şi să identificăm factorii predictivi pentru apariția evenimentelor tromboembolice venoase, în special parametrii legați de hemostază. Material si metode: Am efectuat un studiu prospectiv observațional incluzând consecutiv pacienți adulți cu nefropatie membranoasă idiopatică confirmata bioptic şi sindrom nefrotic. Diagnosticul de sindrom nefrotic a fost confirmat prin prezența unei proteinurii de peste $3,5 \mathrm{~g} / \mathrm{zi}$. Datele clinice şi biologice, inclusiv parametrii legați de sistemul coagulării şi cel fibrinolitic, au fost monitorizate la fiecare 6 luni de-a lungul perioadei de urmărire. Apariția evenimentelor tromboembolice venoase a fost end-point-ul primar al studiului. Rezultate: Am înrolat 56 de pacienți $(52 \pm 11$ ani, 64\% bărbați). Perioada medie de urmărire a fost de 12 [IQR: 12, 33] luni. De-a lungul perioadei de urmărire am înregistrat 11 ETV, $91 \%$ din ele apărând în primele şase luni de urmărire. Proteinuria de baza şi albumina serică au fost asociate cu ETV ( $p<0,001)$. In ceea ce priveşte parametrii hemostazei, activitatea antitrombinei III (AT III), activitatea proteinei C, nivelurile inhibitorului activatorului de plasminogen (PAI-1) şi al activatorului tisular al plasminogenului (tPA) au fost asociate cu un risc crescut de evenimente tromboembolice venoase (toate $p<0,05$ ), în timp ce activitatea proteinei $S$ şi nivelul fibrinogenului nu au fost asociate cu un risc crescut. Analiza multivariată prin modelul riscului proporțional Cox a identificat doar activitatea AT III ( $\operatorname{Exp}(B) 0.86,95 \%$ CI 0.75\% la 0.98; p=0.027) şi nivelul albuminei serice (Exp (B) 0.062, $95 \%$ CI 0.01 la 0.37; $p=0.002$ ) ca factori de risc independenti pentru ETV. Concluzii: În acest studiu prospectiv riscul de ETV a fost mai ridicat în primele şase luni de urmărire şi dintre factorii de risc legati de hemostaza, doar activitatea AT III a fost identificata ca factor de risc independent pentru apariția ETV la pacienții cu nefropatie membranoasă idiopatică şi sindrom nefrotic.

Cuvinte cheie: Antitrombina III, D-dimeri, nefropatie membranoasă, sindrom nefrotic, tromboză.

Received: 14 ${ }^{\text {th }}$ February 2013; Accepted: 28 $8^{\text {th }}$ April 2013; Published: $15^{\text {th }}$ May 2013.

\section{Introduction}

The nephrotic syndrome (NS), irrespective of its etiology and histologic pattern of glomerular lesions, is associated with an increased incidence of thromboembolic complications. Thromboembolic events are an important cause of morbidity and mortality in these patients $(1,2)$.

Venous thromboembolic events (VTE) encountered in NS are deep venous thrombosis, pulmonary embolism and renal vein thrombosis. There is an increased variability in venous thromboembolic events reporting rate in patients with NS, most probably related to methodologic issues such as the retrospective study design and the lack of standardized and accurate methods to detect venous thrombosis (2-4).

Multiple abnormalities in haemostasis and coagulation system occurring in patients with NS are due to various mechanisms, not fully clarified, such as preferential urinary loss of proteins involved in the inhibition of systemic haemostasis, increased synthesis of procoagulation proteins, local activation of glomerular haemostasis, platelets hyperactivity, thrombocytosis, fibrinolytic system abnormalities (2, 5-7).

Although some factors predicting the risk of VTE in patients with NS have been already identified, there are not enough data in the literature to establish the individual risk of the single patient with NS to develop such an event and also the indication of prophylactic therapy $(8,9)$.

We conducted a multi-center prospective observational study and we sought to answer the following questions: 1) Which is the absolute risk of VTE in a large cohort of patients with idiopathic membranous nephropathy and NS?; 2) Which are the predictive factors for VTE in these patients, focusing on haemostasis-associated risk factors; 3) Is there an independent risk factor for predicting VTE in this setting? 


\section{Methods}

\section{Patients}

All consecutive patients with idiopathic membranous nephropathy confirmed by renal biopsy and NS admitted to our departments between January 2003 and March 2010 were considered for inclusion. The diagnosis of NS was confirmed by a persistent protein excretion greater than $3.5 \mathrm{~g} / 24$ hours.

Exclusion criteria were age under 16, an identified condition responsible for glomerulonephritis, e.g. secondary glomerulonephritis, serum creatinine over $3 \mathrm{mg} / \mathrm{dL}$, and therapy influencing haemostasis (antiplatelet drugs, anticoagulants). Patients with incomplete data or a less than 12 months follow-up were also excluded.

The final study population included 56 patients. A renal biopsy was performed in 191 patients. All patients were treated with immunosupressive theraphy and corticosteroids, according to guidelines.

\section{Study parameters}

The study parameters were glomerular filtration rate (MDRD formula) (10), proteinuria (24 hours urine collection), serum albumin and blood lipids (cholesterol and triglycerides).

The coagulation parameters monitored were prothrombin time (PT), activated partial thromboplastin time (APTT), fibrinogen, serum ionic calcium, natural anticoagulants such as antithrombin (AT) III, protein C (PC) and total protein S (PS) activity. The fibrinolytic system was assessed by plasminogen activator inhibitor-1 (PAI-1), and tisular plasminogen activator (tPA) measurements. D-dimers (DDi) were used as markers of intravascular thrombosis.

All the assays were performed in our laboratories on the day the specimens were obtained. AT III activity, serum fibrinogen, PC activity, PS activity, PAI-1, DDi were assessed using a STA Compact (Diagnostica Stago) coagulation analyzer and commercial kits (Diagnostica Stago).

Thromboembolic events were suspected on clinical grounds and/or by increase in DDi titer, and confirmed by imaging techniques: deep vein thrombosis by Doppler ultrasound, renal vein thrombosis by Doppler ultrasound and contrast spiral computed tomography (CT), and pulmonary embolism by contrast spiral CT.

\section{Study design}

This was a prospective study. Data were obtained at the first admission, every 6 months at follow-up or at the time of thromboembolic event occurrence.

In order to evaluate the prognostic utility of the variation in DDi levels for thromboembolic events occurence, whenever a DDi higher than $2 \mathrm{mcg} / \mathrm{ml}$ was noted at follow-up, pulmonary and abdominal contrast spiral computed tomography (CT), and limb vein Doppler ultrasoundwere performed. A $2 \mathrm{mcg} / \mathrm{ml}$ cut-off for DDi was used, as supported in studies in other settings (deep vein thrombosis, systemic lupus erythematosus) (15).

\section{Statistical analysis}

Normally distributed variables are expressed as mean \pm standard deviation. Nonparametric variables were described as median (lower quartile and upper quartile). For continuous variables, differences between groups were assessed with Student's t test, Mann-Whitney U test, depending on the normality of the data.Categorical variables were compared with the $\chi^{2}$ test. All $p$-values are two tailed, with $p<0.05$ considered statistically significant.

Receiver operator characteristic (ROC) curve analysis was performed to evaluate the utility and to identify cut-off values for parameters significantly correlated with the risk of VTE.

The time to event was measured from baseline to the moment of a documented VTE. Kaplan Meier survival free of event (VTE) curves were computed for different variables as predictors of outcome.

Differences in event-free survival were determined using the Cox proportional hazards test. Variables included in the multivariate analysis were selected on the basis of the best results of univariate analyses (at a significance 
Table 1. Baseline demographic, clinical and biological characteristics of patients in the entire study population and risk factors associated with venous thromboembolic events

\begin{tabular}{lcccc}
\hline Parameter & All & Patients with VTE & $\begin{array}{c}\text { Patients without } \\
\text { VTE }\end{array}$ & $\begin{array}{c}\text { Patients with VTE } \\
\text { vs without VTE } \\
\text { ( } \mathbf{p} \text { value) }\end{array}$ \\
\hline Age (years) & $52.2 \pm 10.7$ & $50.5 \pm 11$ & $52.6 \pm 11$ & 0.57 \\
Gender (\% male) & 64.3 & 45.4 & 68.9 & 0.015 \\
Median follow-up time (months) & 12 & 12 (IQR:12,18) & 24 (IQR:12,36) & 0.20 \\
& $(\mathrm{IQR}: 12,33)$ & & $82.2 \pm 13.2$ & 0.084 \\
eGFR & $83.6 \pm 13$ & $89 \pm 10.5$ & $8.2 \pm 1.7$ & $<0.001$ \\
Proteinuria (g/24h) & $8.67 \pm 1.9$ & $10.6 \pm 1.4$ & $2.5 \pm 0.48$ & $<0.001$ \\
Serum albumin (g/dl) & $2.27 \pm 0.7$ & $1.2 \pm 0.47$ & $315 \pm 47$ & 0.52 \\
Serum cholesterol (mg/dl) & $321 \pm 48$ & $346 \pm 45$ & $250 \pm 40$ & 0.82 \\
Serum triglycerides(mg/dl) & $251 \pm 43$ & $254 \pm 54$ & $724 \pm 93$ & 0.35 \\
Fibrinogen (mg/dl) & $732 \pm 104$ & $767 \pm 140$ & $36.1 \pm 3.9$ & 0.34 \\
APTT(s) & $35.8 \pm 4.1$ & $34.6 \pm 4.6$ & $14.5 \pm 1.1$ & 0.17 \\
PT (\%) & $14.7 \pm 1.1$ & $15 \pm 0.9$ & $75.8 \pm 6.8$ & $<0.001$ \\
ATIII activity (\%) & $73.2 \pm 8.7$ & $62.5 \pm 7.4$ & $108.9 \pm 19.9$ & 0.003 \\
Protein C activity (\%) & $113.3 \pm 21.4$ & $131.4 \pm 18.5$ & $80.6 \pm 9.9$ & 0.51 \\
Protein S activity(\%) & $80.1 \pm 10.1$ & $78.1 \pm 10.9$ & $60.2 \pm 8.6$ & 0.045 \\
PAI-1 (ng/ml) & $62 \pm 10.2$ & $69.4 \pm 13.1$ & $5.3 \pm 1.5$ & 0.005 \\
tPA(ng/ml) & $4.9 \pm 1.6$ & $3.6 \pm 1.5$ & $0.84 \pm 0.77$ & 0.458 \\
DDi (mcg/ ml) & $1.34 \pm 1.4$ & $0.93 \pm 0.52$ & & \\
\hline
\end{tabular}

Data are presented as mean and standard deviation.

APTT - activated partial thromboplastin time; ATIII - antithrombin III activity; eGFR - estimated glomerular filtration rate; PAI-1 - plasminogen activator inhibitor-1; PT - prothrombin time; tPA - tisular plasminogen activator; DDi, D-dimers;VTE - venous thromboembolic event.

level of $p<0.05)$. Results were expressed as hazard ratios $(\operatorname{Exp} \beta)$ with $95 \%$ CIs.

Statistical analysis was performed using SPSS for Windows version 17.0 (SPSS, Inc., Chicago, IL).

\section{Results}

\section{Patient characteristics}

The study population included 56 patients with primitive NS. Baseline characteristics of the study population are displayed in Table 1. Sixtyfour percents were male patients, the median follow-up duration was 12 [IQR: 12, 33] months, the baseline proteinuria was $8.7 \pm 1.9 \mathrm{~g} /$ day and baseline serum albumin was $2.2 \pm 0.7 \mathrm{~g} / \mathrm{l}$. Baseline coagulation parameters in the entire study population are illustrated in Table 1.

Venous thromboembolic events: frequency

During follow-up 11 VTE occurred. The most commonly encountered first VTE was DVT (36.4\%) and pulmonary embolism $(18.2 \%)$, followed by renal vein thrombosis (9.1\%), combined pulmonary embolism and DVT $(9.1 \%)$, combined pulmonary embolism and renal vein thrombosis $(9.1 \%)$, other vein thrombosis (18.2\%) (Figure 1).

Median follow-up until the occurrence of VTE was 3 [IQR:1,4] from baseline, and 91\% of VTE occurred in the first 6 months. The cumulat- 

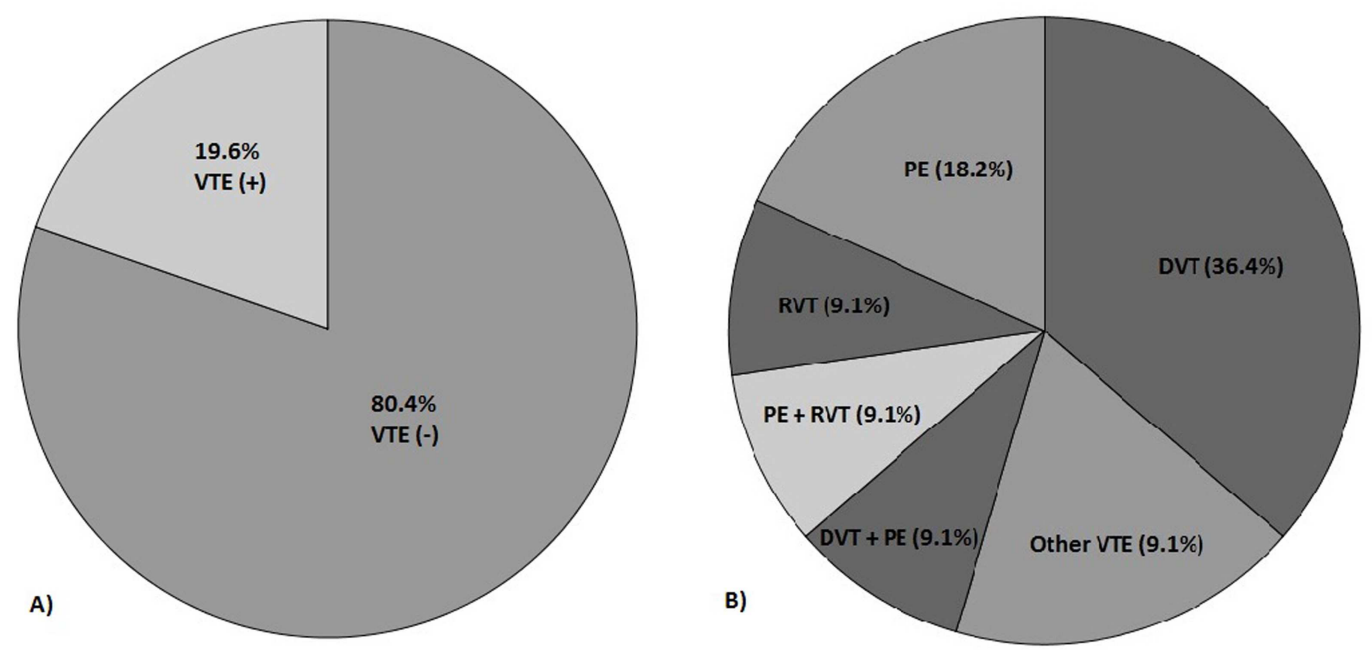

Figure 1. Venous thromboembolic events (VTE) frequency (A) and type (DVT - deep vein thrombosis; PE - pulmonary embolism; RVT - renal vein thrombosis) (B)

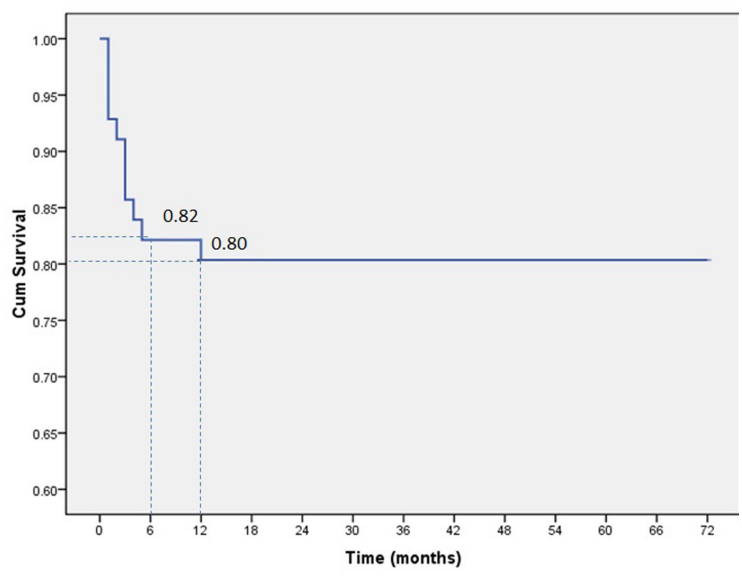

Figure 2. The cumulative probability of survival without a venous thrombotic event (Kalpan-Meier analysis).

ive probability of event-free survival abruptly decreased to $82 \%$ and $80 \%$ at 6 and 12 months, and remained stable thereafter (Figure 2).

Venous thromboembolic events: risk factors

The results of univariate analyses to identify clinical features associated with the development of VTE are shown in Table 1 . Baseline proteinuria and serum albumin were associated with VTE, whereas hypercholesterolemia, hypertriglyceridemia and eGFR were not. As for the haemostatic parameters, ATIII activity, PC activity, PAI-1 and tPA levels were associated with an increased risk of VTE, while fibrinogen and PS activity were not. The risk of VTE was directly proportional to the severity of proteinuria and PAI-1 level and inversely related to the serum albumin, ATIII activity, PC activity and tPA levels (Table 1).

After using a Cox proportional hazards model including the variables which significantly correlated with the risk of VTE at univariate analysis, only the ATIII activity and serum albumin remained independently associated with thrombotic events (Table 2).

ROC curve analysis was performed to identify the cut-off values for serum albumin and ATIII activity which predict the development of a VTE in NS patients with a good sensitivity and specificity. Thus, a serum albumin level of $1.75 \mathrm{~g} / \mathrm{dl}$ has a sensitivity of $83.4 \%$ and a specificity of $63.6 \%$ to predict a VTE, and an ATIII activity of $67.5 \%$ has a sensitivity of $83.8 \%$ and a specificity of $81.8 \%$ as a risk factor for VTE in NS patients (Figure 3).

In order to confirm the cut-off value of DDi to identify VTE in NS patients, we performed a ROC curve analysis (Figure 4) and 
Table 2. Risk factors associated with venous thromboembolic events in patients with nephrotic syndrome - multivariable analysis using a Cox proportional hazards model

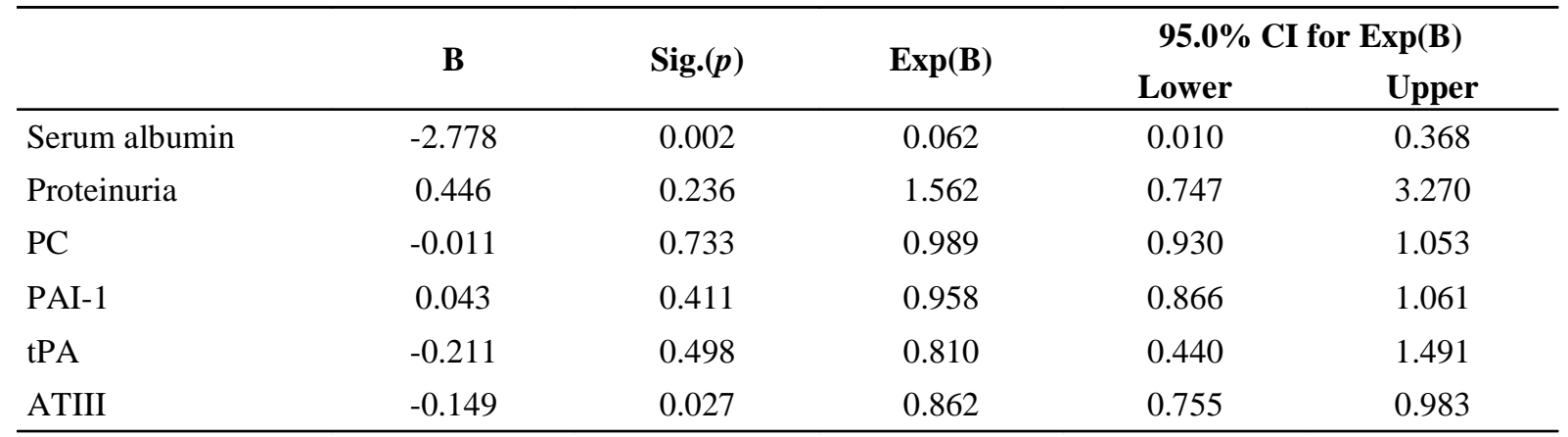

ATIII, antithrombin III activity; PAI-1, plasminogen activator inhibitor-1; PC, protein C; PT, prothrombin time; tPA, tisular plasminogen activator.

found an $86.5 \%$ specificity and $90.9 \%$ sensitivity for the DDi value of $2 \mathrm{mcg} / \mathrm{ml}$ to predict the occurrence of a VTE.

\section{Discussion}

The main findings of our prospective study are the epidemiological description of VTE occurrence in a large cohort of patients with idiopathic membranous nephropathy and NS and the identification of biological parameters such as serum albumin levels and coagulation parameters as risk factors for VTE. To our knowledge this is the first study assessing prospectively the predictive value of haemostasis-related parameters for the risk of VTE in NS patients. The risk of thromboembolic events is higher in patients with NS as compared with any other medical condition and it is a severe complication associated with significant morbidity and mortality $(11,12)$.

Unlike other studies, we used DDi level assessment as a screening method for VTE. The VTE incidence confirmed by imaging techniques was $19.6 \%$ and $54 \%$ of these events were simptomatic. This higher incidence, compared with other reports, could result from using a VTE screening method in our study (5). The entire follow-up in our study was $21.9 \pm$
14.9 months. Median time to first VTE was 3 months, and $91 \%$ of the events occurred in the first 6 months and $100 \%$ in the first year.

Although there are various studies demonstrating the DDi value as the test with the highest specificity and sensitivity for DVT and pulmonary emboli in general population, there are few studies using DDi levels monitoring as a screening test for VTE in patients with NS (13-15). In our study population, $25 \%$ of patients with peak DDi $>2 \mathrm{mcg} / \mathrm{ml}$ had VTE and this cut-off value had an $86.5 \%$ specificity and a $90.9 \%$ sensitivity to predict VTE occurence.

Proteinuria degree and serum albumin levels are the most studied risk factors for VTE in patients with NS. In some but not all studies, this risk increases proportionally with proteinuria severity and decreased serum albumin levels. In our study, only the decreased baseline serum albumin levels were independent predictive factor for VTE.

Several studies investigated the histological pattern as an independent risk factor for VTE. Data regarding the histological pattern impact on VTE risk in patients with primitive NS are controversial. In one study including 298 NS patients, from whom 157 had primitive GN, there were no differences in VTE incidence according to histological pattern (16). An- 


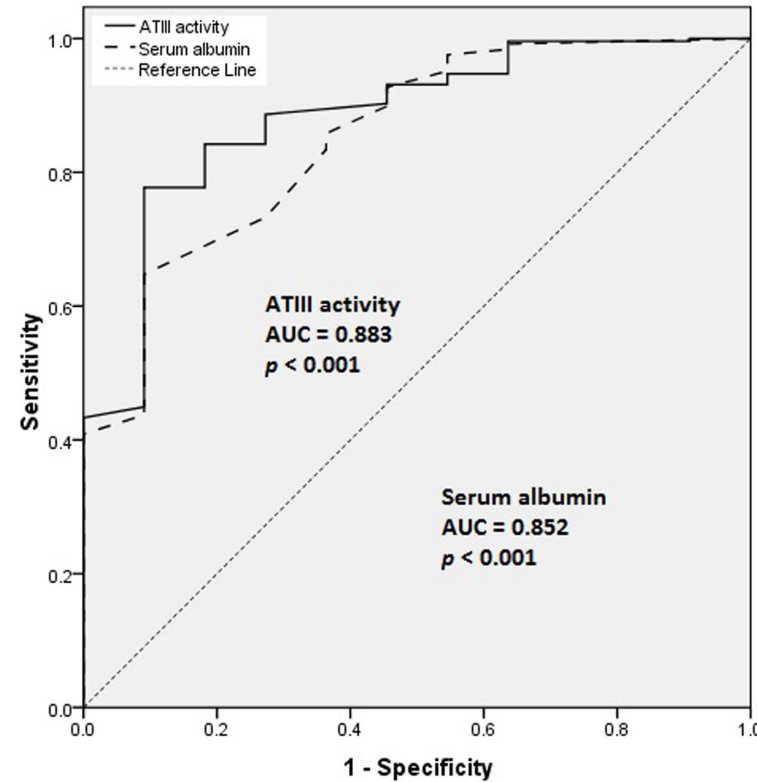

Figure 3. The serum albumin and ATIII activity diagnostic utility for VTE occurence (ROC curve analysis)

other study showed in a cohort of more than 1300 patients with primitive NS that histologic pattern is a predictive factor independent of proteinuria and serum albumin level (8). In order to avoid the bias effect of histologic pattern upon the risk of VTE, in our study whe have selected only the patients with idiopathic membranous nephropathy and NS.

The risk of thromboembolic events development in NS patients correlates with changes in haemostasis parameters occuring in these patients, but it remains to be clarified if the risk associated with haemostasis changes and quantified by coagulation parameters is independent of conventional risk factors such as proteinuria degree or serum albumin levels $(2,16,17)$. In our study, the univariate analysis showed that ATIII activity, PC activity, tPA and PAI-1 were risk factors for VTE, while fibrinogen and PS activity were not significantly associated with VTE. After including these parameters in a multivariable analysis using a Cox regression model, only ATIII activity emerged as an independent predictive factor for VTE.

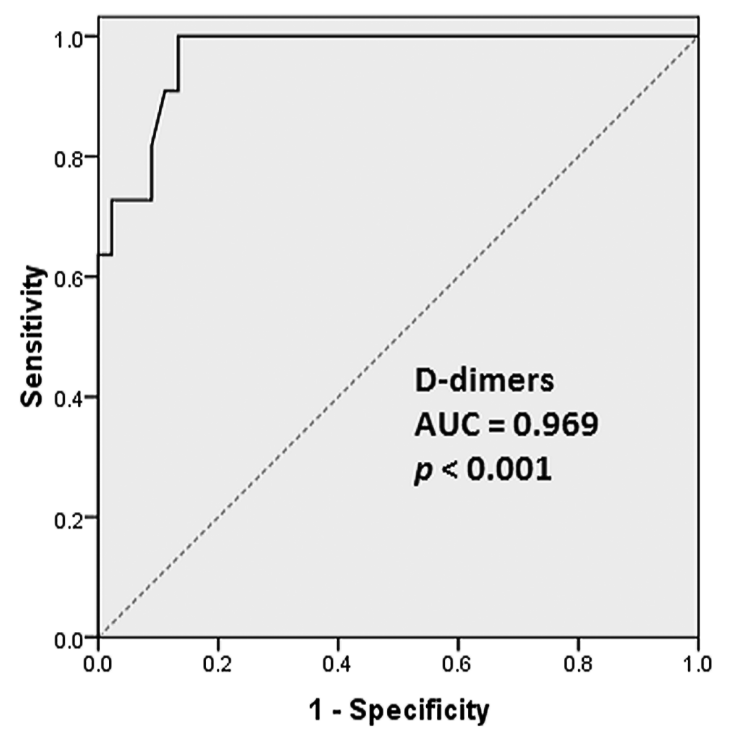

Figure 4. The diagnostic utility of the increase in Ddimers levels for VTE occurence (Receiver operator curve analysis)

ATIII is the most important coagulation and thrombin inhibitor. Multiple studies reported decreased ATIII serum concentration (18, 19). The low ATIII molecular weight is similar with albumin molecular weight and this is one of the important molecules involved in coagulation system with urinary loss in patients with NS. Antithrombin deficiency has been associated with DVT and PE in some studies $(20,21)$, but not in others (7). In this study we identified a decreased ATIII activity as an independent predictive factor for VTE (Table 2).

Alterations in thrombolytic activity are described in patients with NS (2). Tissue plasminogen activator (tPA) together with plasminogen activator inhibitor-1 (PAI-1) are two key regulators of plasmin formation. At present, there are few and controversial data on the tPA levels in NS patients: some studies report a significant increase of tPA (22), while others identify a decrease in tPA levels in this setting (23). Data regarding tPA levels impact on VTE occurrence are scarce. We showed that patients with idiopathic membranous nephropathy and 
NS experiencing a VTE had significantly lower levels of tPA as compared with patients without VTE during follow-up (Table 1). Patients with VTE had significantly higher levels of PAI-1 levels as compared with patients without VTE in our study (Table 1). In our study, the multivariable analysis has failed to identify tPA and PAI-1 as independent risk factors for VTE in patients with idiopathic membranous nephropathy and NS (Table 2).

Study strengths. We performed a prospective observational study on a large number of patients with long follow-up in which we used a screening method for thromboembolic events and we assessed multiple biological parameters including coagulation parameters.

Study limitations. The patients in our study are a selected cohort of patients as they are followed-up in a tertiary center but this was minimalised because consecutive patients were analyzed.

\section{Conclusion}

In this prospective study the absolute risk of VTE was higher in the first 6 months of followup. ATIII deficiency and serum albumin levels emerged as VTE independent risk factors in patients with idiopathic membranous nephropathy and NS. Further studies to investigate the effect of ATIII deficiency and serum albumin level correction on VTE risk in patients with NS are needed.

\section{References}

1. Llach F: Hypercoagulability, renal vein thrombosis, and other thrombotic complications of nephrotic syndrome. Kidney Int. 1985; 28:429.

2. Singhal R, Brimble KS: Thromboembolic complications in the nephrotic syndrome: pathophysiology and clinical management. Thromb Res. 2006; 118:397.

3. Wei LQ, Rong ZK, Gui L, Shan RD: CT diagnosis of renal vein thrombosis in nephrotic syndrome. J Comput Assist Tomogr. 1991; 15:454.

4. Llach F, Papper S, Massry SG: The clinical spectrum of renal vein thrombosis: acute and chronic. Am J Med. 1980; 69:819.

5. Wagoner RD, Stanson AW, Holley KE, Winter CS:
Renal vein thrombosis in idiopathic membranous glomerulopathy and nephrotic syndrome: incidence and significance. Kidney Int. 1983; 23:368.

6. Sarasin FP, Schifferli JA: Prophylactic oral anticoagulation in nephrotic patients with idiopathic membranous nephropathy. Kidney Int. 1994; 45:578.

7. Robert A, Olmer M, Sampol J, Gugliotta JE, Casanova P: Clinical correlation between hypercoagulability and thrombo-embolic phenomena. Kidney Int. 1987; $31: 830-5$.

8. Barbour SJ, Greenwald A, Djurdjev O, Levin A, Hladunewich NA, Nachman PH et al: Disease-specific risk of venous thromboembolic events is increased in idiopathic glomerulonephritis. Kidney Int. 2012; 81:190.

9. Lionaki S, Derebail VK, Hogan SL, Barbour SJ, Lee $\mathrm{T}$, Hladunewich NA et al: Venous thromboembolism in patients with membranous nephropathy. Clin J Am Soc Nephrol. 2012; 7:43.

10. Levey AS, Greene T, Kusek JW, Beck GJ, MDRD Study Group: A simplified equation to predict glomerular filtration rate from serum creatinine. J Am Soc Nephrol., 2000, 11:A0828.

11. Andrassy K, Ritz E, Bommer J: Hypercoagulability in the nephrotic syndrome. Klin Wochenschr. 1980; 58:1029-36.

12. Cameron JS. The nephrotic syndrome and its complications. Am. J. Kidney Dis. 1987 Sep;10(3):157-71.

13. Di Nisio M, Squizzato A, Rutjes AW, Buller HR, Zwinderman AH, Bossuyt PM: Diagnostic accuracy of Ddimer test for exclusion of venous thromboembolism: A systematic review. J Thromb Haemost 2007; 5: 296 -304.

14. Mannucci PM, Valsecchi C, Bottasso B, D'Angelo A, Casati S, Ponticelli C: High plasma levels of protein C activity and antigen in the nephritic syndrome. Thromb Haemost 1986; 55(1): 31-33.

15. Haifeng Wu, Birmingham DJ, Rovin B, Hackshaw KV, Haddad N, Haden D et al: D-Dimer level and the risk for thrombosis in systemic lupus erythematosus.Clin J Am Soc Nephrol. 2008; 3: 1628-1636.

16. Mahmoodi BK, ten Kate MK, Waanders F, Veeger NJ, Brouwer JL, Vogt L et al: High absolute risks and predictors of venous and arterial thromboembolic events in patients with nephrotic syndrome: results from a large retrospective cohort study. Circulation 2008; 117:224.

17. Glassock RJ: Prophylactic Anticoagulation in Nephrotic Syndrome: A Clinical Conundrum. J Am Soc Nephrol. 2007;18: 2221-2225.

18. Kauffrnann RH, Veltkamp JJ, Van Tilburg NH, Van Es LA: Acquired antithrombin III deficiency and thrombosis in the nephrotic syndrome. Am J Med. 1978;65:60713.

19. Boneu B, Bouissou F, Abbal M, Sie P, Caranobe C, Barthe P: Comparison of progressive antithrombin activity and the concentration of three thrombin inhibitors in nephrotic syndrome. Thromb Haemost. 1981;46:623-5.

20. Chemg SC, Huang WS, Wang YF, Yang SP, Lin YF: 
The role of lung scintigraphy in the diagnosis of nephrotic syndrome with pulmonary embolism. Clin Nucl Med 2000; 25:167-72.

21. Citak A, Emre S, Sairin A, Bilge I, Nayir A: Hemostatic problems and thromboembolic complications in nephrotic children. Pediatr Nephrol 2000;14:138- 42.

22. Vaziri ND, Gonzales EC, Shayestehfar B, Barton
CH: Plasma levels and urinary excretion of fibrinolytic and protease inhibitory proteins in nephrotic syndrome. $\mathrm{J}$ Lab Clin Med 1994; 124(1):118-124.

23. Hamano K, Iwano M, Akai Y, Sato H, Kubo A, Nishitani Y et al: Expression of glomerular plasminogen activator inhibitor type 1 in glomerulonephritis. Am J Kidney Dis 2002; 39:695- 705. 